\title{
Eila Riikonen
}

\section{Kokemuksia ammattikoulun opettajien työsuojelukoulutuksesta}

Tampereen aluetyöterveyslaitos on järjestänyt ammatillisten oppilaitosten opettajille täydennyskoulutuksena työsuojelukursseja vuodesta 1978 lähtien. Artikkelissa esitellään kurssien lähtökohtia, sisältöjä ja resursseja sekä arvioidaan koulutuksen kehittämistarpeita.

\section{Keskiasteen \\ uudistuskeskustelusta se alkoi}

Oppilaitosten työsuojeluopetusta on käsitelty useassa työryhmässä keskiasteen koulunuudistuksen käynnistyttyä 1970-luvun lopulla. Opetussuunnitelmien uudistamisella pyritään vastaamaan työelämän muutoksen aiheuttamiin uusiin ammattitaitovaatimuksiin. Työsuojelu katsotaan osaksi ammattitaitoa.

Opetusministeriön asettama työsuojeluopetusta selvittelevä työryhmä suositteli työsuojeluopetusta annettavaksi läpäisyperiaatteella eri oppiaineiden yhteydessä sekä erillisenä työsuojeluopetuksena. Myös opettajakoulutukseen sisältyvää työsuojeluopetusta ja oppimateriaalin kehittämistä pidettiin tärkeänä (Opetusministeriö 1977). Koulujen työsuojeluopetukseen on sittemmin kiinnitetty huomiota $\mathrm{mm}$. ammattikasvatushallituksen työsuojeluopetusohjeistossa (AKH 1982, AKH:n OPS-tiedote 1983:3), valtakunnallisessa työympäristöohjelmassa (sosiaali- ja terveysministeriö 1983, 28-29, 44) ja sosiaali- ja terveysministeriön työsuojelun koulutus- ja tiedotustyöryhmässä (STM. Työryhmä 1986:14, 5-7). Näissä kaikissa asiakirjoissa korostuu keskiasteen ammatillisen koulutuksen tehtävä yleisen ja ammattikohtaisen työsuojelutiedon jakajana. Opetussuunnitelmien (yhteensä 250) uudistamistyön yhteydessä on jossain määrin otettu huomioon myös työn ja terveyden väliset yhteydet (AKH 1984, 42-46).

Ammattikoulujen työsuojeluopetuksen ongelmiksi on todettu opettajien puutteelliset työsuojelutiedot ja sopivan oppimateriaalin puute. Vain osa opettajista on saanut oman ammatillisen peruskoulutuksensa yhteydessä työsuojeluopetusta. Opettajaopistoissa työsuojeluopetus käynnistyi vasta 1970-luvun lopulla. Parhaillaan (vuoden 1987 syksyllä) ammattikasvatushallituksen työryhmä selvittää opettajien työsuojelun täydennyskoulutusmahdollisuuksia.

Opettajien työsuojelukoulutus on ollut osa ammattikasvatushallituksen rahoittamaa ulkopuolisten kouluttajatahojen järjestämää ala- ja ammattikohtaista täydennyskoulutusta, joka voi olla ammatillista, pedagogista tai mukauttamiseen (keskiasteen uudistus) liittyvää. Sen kestoksi on määritetty 3-4 päivää. Sisällöllisesti kursseilta on edellytetty ehjää kokonaisuutta ja keskittymistä alan kehityksen kannalta olennaisin aiheisiin. Luentomuotoisen opetuksen lisäksi on suositeltu harjoituksia, ryhmätöitä ja kokeita tavoitteiden saavuttamisen toteamiseksi (AKH 1983: Opettajien täydennyskoulutuskurssiesityksen laadintaohje).

\section{Yhteistyötä ammatti- kasvatushallituksen kanssa}

Tampereen aluetyöterveyslaitos lähti mukaan opettajien täydennyskoulutukseen vuonna 1978 tarjoamalla ammattikasvatushallitukselle opettajien työsuojelukursseja. Aluetyöterveyslaitoksen kiinnostus ko. koulutuksen järjestämiseen on perustunut seuraaviin seikkoihin:

- Työterveyslaitos on määritellyt erääksi koulutustehtäväkseen osallistumisen keskiasteen ammatillisten oppilaitosten työsuojelukoulutuksen kehittämiseen (Työterveyslaitos 1981, 12).

- Opetusministeriön työsuojeluopetustyöryhmässä oli Työterveyslaitoksen edustajina aluelaitoksen kouluttaja. Näin ammatillisten oppilaitosten työsuojeluopetuksen ongelmista keskusteltiin Työterveyslaitoksen koulutushenkilöstön piirissä.

- Aluetyöterveyslaitos on palvelu- ja tutkimustoimintansa yhteydessä hankkinut teollisten alojen työolokokemusta. 
- Työsuojeluhallinnon toiminta oli voimakkaasti teollisuuspainotteinen ja työsuojelupiiristä ja työsuojeluhallituksesta oli saatavissa asiantuntija-apua lähinnä koneturvallisuuskysymyksiin.

Kurssit on suunniteltu AKH:n ohjeiden mukaan. Suunnitelmissa on ilmoitettu kurssin nimi, keskeinen sisältö ja taso, osanottajien arvioitu määrä, kohderyhmät, osanottajilta edellytetyt etukäteistiedot (työsuojelun perustiedot) ja kustannusarvio. Opetussuunnitelmaosa on sisältänyt kuvauksen kurssin tavoitteesta ja aihealueittaisen tuntijaon. Yleensä kurssisuunnittelu on käynnistynyt noin $1 / 2$ vuotta ennen toteutetusta ja kurssivahvistukset on saatu $\mathrm{AKH}$ :sta noin $4 \mathrm{kk}$ ennen toteutusta.

Ammattikasvatushallitus ja Tampereen aluetyöterveyslaitos ovat tiedottaneet kursseista suoraan kouluille. Koulutustilaisuudet on järjestetty yleensä kesäkuun alussa. AKH on edellyttänyt opetuspäiväkirjan pitoa ja kustannuserittelyä laskutuksen perusteiksi. Kustakin kurssista on arkistoitu mallikansio ja kurssilla jaettu muu materiaali sekä arviointien yhteenvedot ja kirjeenvaihto AKH:n kanssa.

Tampereen aluetyöterveyslaitos on vuosina 1978-1987 järjestänyt yhteensä 16 työsuojelukurssia ammattikoulujen ja ammatillisten kurssikeskusten teollisten alojen opettajille.
Kurssit on järjestetty tilauskurssiperiaatteella. AKH on korvannut kaikki välittömät opetuspalkkiot ja materiaalikulut ja osan välillisistä kuluista. Osanottajille kurssit ovat olleet ilmaisia. Ammattikasvatushallitus on kurssikustannusten lisäksi maksanut osanottajien matkaja majoituskulut. Opetus on pääosin hoidettu aluetyöterveyslaitoksen omin voimin. Ulkopuolisten asiantuntijoiden osuus on ollut vajaa neljännes. Aluetyöterveyslaitos on käyttänyt työaikaa (suunnittelu ja opetus) opettajien täydennyskoulutukseen yhteensä yli 2 henkilötyövuotta. Kurssia kohden on käytetty työaikaa keskimäärin $2 \mathrm{kk}$.

Opettajien työsuojelukurssit on toteutettu normaalin vuosittaisen koulutusohjelman ulkopuolella. Aluelaitos järjestää vuosittain 2530 kurssia, joille osallistuu $600-700$ henkeä. Koulutettavapäiviä kertyy noin 2 100. Työsuojelu- ja työterveyshenkilöstö muodostavat valtaosan koulutettava joukosta.

\section{Lyhytkursseja teollisilta aloilta}

Opettajien kurssit on suunnattu teollisille aloille. Eniten on koulutettu metalli- ja autoalojen opettajia. Rakennusalan kursseja on jouduttu pitämään alle 15 hengen ryhmille (taulukko 1).

TAULUKKO 1. Ammattikoulujen ja ammatillisten kurssikeskusten opettajien työsuojelukurssit Tampereen aluetyöterveyslaitoksessa vuosina 1978—98, kesto, osanottajat ja koulutettavapäivät

\begin{tabular}{|c|c|c|c|c|c|}
\hline kürssi & vuosi & $\begin{array}{l}\text { kesto } \\
\text { päivää }\end{array}$ & tuntia & $\begin{array}{l}\text { osan- } \\
\text { ottajat }\end{array}$ & kpv:t \\
\hline työhygienia & 1978 & 3 & 24 & 26 & 78 \\
\hline työhygienia & 1978 & 3 & 24 & 20 & 60 \\
\hline metalli- ja autoala & 1979 & 4 & 32 & 22 & 88 \\
\hline metalli- ja autoala & 1979 & 4 & 32 & 25 & 100 \\
\hline metalli- ja autoala & 1980 & 4 & 32 & 23 & 92 \\
\hline metalli- ja autoala & 1981 & 4 & 32 & 24 & 96 \\
\hline metalli- ja autoala & 1982 & 4 & 30 & 28 & 112 \\
\hline $\begin{array}{l}\text { kone-, metalli-, ja } \\
\text { autoalat }\end{array}$ & 1983 & 4 & 31 & 28 & 112 \\
\hline $\begin{array}{l}\text { kone-, metalli- ja } \\
\text { autoalat } \\
\text { pintakäsittelytyön }\end{array}$ & 1986 & 4 & 29 & 23 & 92 \\
\hline työhygienia & 1982 & 3 & 24 & 26 & 78 \\
\hline puuala & 1983 & 4 & 29 & 22 & 88 \\
\hline $\begin{array}{l}\text { tekstiili- ja } \\
\text { vaatetusalan ergonomia } \\
\text { ja työhygienia }\end{array}$ & 1986 & 4 & 31 & 20 & 80 \\
\hline rakennusala & 1980 & 4 & 32 & 14 & 56 \\
\hline rakennusala & 1981 & 4 & 32 & 10 & 40 \\
\hline rakennusala & 1982 & 4 & 34 & 12 & 48 \\
\hline rakennusala & 1987 & 3 & 28 & 14 & 42 \\
\hline yhteensä 16 kurssia & & 60 & 476 & 337 & 1262 \\
\hline
\end{tabular}




\section{Kursseille osallistuminen}

Kursseille on osallistunut yhteensä 337 opettajaa, joista suurin osa ammatin- ja työnopettajia. Osanottajat edustavat noin $10 \%$ em. alojen opettajista. Yleisissä ammattikouluissa oli v. 1986 noin 2900 ko. opettajaa. He opettivat yhteensä noin 24950 ammattikoulujen oppilasta. Em. linjojen opettajien peruskoulutuksena on teknikon tai insinöörin tutkinto. Lähes kaikki ovat muodollisesti päteviä opettajatutkinnon suorittaneita. Osa opettajista toimii koulunsa työsuojelun yhteistoimintatehtävissä (Hakkarainen, 1987).

Vuonna 1986 kahdesta opettajakurssista tehdyn selvityksen (Reunanen 1986) mukaan osanottajista (n. 43) yli puolet oli saanut työsuojeluopetusta opettajakoulutuksen yhteydessä ja yli puolet oli osallistunut jollekin työsuojelukurssille ennen aluetyöterveyslaitoksen kurssia. Kyselyyn vastanneista $81 \%$ antoi itse työsuojeluopetusta. Tärkeimpiä opetuksen osa-alueita olivat työturvallisuus, henkilökohtaiset suojaimet ja työn fyysinen kuormittavuus. Työsuojeluopetuksen määrää pidettiin oppilasta kohden sopivana. Ongelmallisiksi mainittiin asennekasvatus, opettajien puutteelliset tiedot ja oppimateriaalin ja havaintomateriaalin puute. Koulujen työtilat ovat usein ahtaat ja koneet ja laitteet vanhentuneita.

\section{Alakohtaiset sisällöt}

Kurssien tavoitteena on ollut lisätä opettajien valmiuksia opettaa työsuojelua ja motivoida opettajia omatoimisesti kehittämään työsuojeluvalmiuksiaan.

Opetuksen sisällöllinen suunnittelu on ollut kurssinvetäjän vastuulla. Kursseilla on ollut kuusi eri vetäjää. Heidän alakohtainen asiantuntemuksensa on perustunut heidän peruskoulutukseensa (eri alojen insinöörejä ja diplomi-insinöörejä) ja työsuojelun asiantuntijatehtäviin. Kurssien vetäjät ovat tehneet suunnitteluyhteistyötä aluetyöterveyslaitoksen eri alojen asiantuntijoiden, työsuojeluhallinnon virkamiesten ja ammattikasvatushallituksen työsuojelun ylitarkastajan kanssa.

Opetus on ollut pääosin luentomuotoista. Se on keskittynyt toimialakohtaisiin työsuojeluongelmiin. Sisällöllinen painopiste on ollut työturvallisuus/tapaturmatorjunta- ja työhygienia-aiheissa. Työsuojeluopetus ammattikouluissa- ja koulujen työsuojelu -aiheisiin on käytetty aikaa noin viidesosa kokonaisajasta.

Eri alojen opettajien työsuojelukurssit ovat sisällöllisesti luonnollisesti eronneet toisistaan, vaikka niissä onkin sama perusrunko. Alakohtaista opetusta on sisältynyt eniten tapaturmantorjunta- ja työhygienia-aiheisiin (taulukko 2).

TAULUKKO 2. Oppisisällöt eräillä alakohtaisilla opettajien työsuojelukursseilla, \% (rakennusala 1982, puuala 1983, kone-, metalli- ja autoalat 1986, tekstiili- ja vaatetusalat 1986).

\begin{tabular}{lcccc}
\hline aihealueet & rakennus & puu & $\begin{array}{l}\text { kone } \\
\text { metalli } \\
\text { auto } \\
(29 \mathrm{~h})\end{array}$ & $\begin{array}{l}\text { tekstiili } \\
\text { vaatetus }\end{array}$ \\
& $(34 \mathrm{~h})$ & $(29 \mathrm{~h})$ & & \\
\hline työturvallisuus & 51 & 21 & 34 & 6 \\
työhygienia & 15 & 28 & 24 & 29 \\
ergonomia & 6 & 14 & 10 & 41 \\
työsuojeluopetus & 15 & 15 & 10 & 6 \\
koulujen työsuojelu & 3 & 9 & 8 & 5 \\
muu & 10 & 13 & 8 & 5 \\
\hline Yhteensä & 100 & 100 & 100 & 100
\end{tabular}

Kurssien yhteisiä oppisisältöjä ovat olleet:

— koulujen työsuojelu, so. työsuojelun valvonta ja vastuu

- tapaturmatorjunnan perusteet

- henkilökohtaiset suojaimet

- työsuojeluopetus ammattikouluissa: oppimateriaali, työsuojeluopetuksen kehittäminen ammattikouluissa, työsuojelu opetussuunnitelmissa.
Alakohtaisesti on käsitelty mm.

- normeja ja ohjeita

- eri töiden ja alojen turvallisuutta (esim. elementtityöt, nostotyön turvallisuus, hitsaustyön turvallisuus)

- koneturvallisuus (esim. puuntyöstökoneet)

- työhygienia (esim. valaistus rakennustyömailla, väriaineet teva-teollisuudessa, ilman epäpuhtaudet hitsaustyössä) 
— työn kuormittavuus (työn kuormittavuus ja sen vähentäminen leikkaamon, ompelimon ja viimeistämön töissä).

Opettajien työsuojelukurssimateriaali on koostunut luennoitsijamonisteista ja painotuotteista (lainsäädäntö, määräykset, normit, työsuojelun oppikirjat, koulutusjulkaisut, työsuojelualan lehtien teemanumerot). Oheismateriaalilla on osittain pystytty korvaamaan koulutuksen lyhtykestoisuus. Oppimateriaali on ollut runsaampaa kuin keskimäärin aluelaitoksen muilla kursseilla. Lisäksi luentosaliin on kurssien ajaksi koottu uusimmista julkaisuista kirjallisuusnäyttely.

\section{Koulutuksen arvioinnista}

Kursseilla on käytetty osanottajien täyttämiä kirjallisia arviointeja, joissa on kysytty kurssin hyödyllisyyttä, uutta tietoa jne. Yleensä osanottajat ovat arvioineet kurssit hyviksi ja odotuksiaan vastaaviksi. Työsuojelun alakohtaisia käytännön sovellutuksia on pidetty tarpeellisina. Työsuojeluopetusta ammattikouluissa on toivottu käsiteltävän perusteellisemmin.

Vetäjät ovat vaihtelevassa määrin tehneet omia arvioitaan kurssin toteutuksesta, esim. luennoitsijoiden opetustavasta ja sisältövalinnoista. Oppimista on arvioitu kirjallisilla kertauskuulusteluilla. Vuonna 1986 tehtiin kahden opettajakurssin opettajille kysely työsuojeluopetuksesta ammattikouluissa (Reunanen 1986). Kurssien kehittämistyö on ollut lähinnä sisällöllistä ja materiaalin hiomista. Suunnitteluun ei ole katsottu voitavan panostaa nykyistä enempää, koska kurssit ovat olleet kertaluonteisia tilauskursseja, joista on tehty päätös vuosittain vajaa puoli vuotta ennen toteutusta.

\section{Johtopäätöksiä ja pohdintaa}

Opettajien työsuojelukoulutus on suuntautunut määrällisesti suurimpiin opettajaryhmiin ja täten koulutuksen vaikutukset ovat parhaimmillaan saattaneet ulottua tuhansiin ammattikoulujen oppilaisiin.

Opettajille koulutus on ollut täydennyskoulutusta. Heiltä on edellytetty työsuojelun perustietoja. Kurssit ovat olleet lyhyitä. Osanottajat ovatkin usein toivoneet pitempää koulutusta. Käytännössä tämä kuitenkin on vaikeaa, koska opettajat eivät mielellään käytä lomaaikaansa opiskeluun ja $\mathrm{AKH}$ on määritellyt kurssien keston 3-4 päiväksi. Sisällöllisesti kurssit ovat keskittyneet perinteisiin alakohtaisiin työsuojeluongelmiin. Opettajien työsuojelukoulutuksen kehittäminen edellyttäisikin se- kä hallinnollisia ratkaisuja että sisällöllistä kehittämistyötä. Opettajien täydennyskoulutusjärjestelmässä työsuojeluopetus muodostaa ehkä noin yhden prosentin koulutustarjonnasta ja joutuu kilpailemaan esim. tietotekniikkakoulutuksen kanssa. Laaja-alainen, nykyaikainen työsuojelun sisällön määrittely mahdollistaa työsuojelunäkökulman mukaanoton mihin tahansa työelämää ja sen kehittämistä käsittelevään koulutukseen.

Järjestäjän kannalta vuosittaiset kertaluontoiset päätökset kurssien järjestämiseksi eivät innosta kehittämistyöhön. Opettajat eivät myöskään voi pitkäjännitteisesti suunnitella omaa työsuojelukoulutustaan nykyisessä tilanteessa. AKH:n, koulujen ja Työterveyslaitoksen yhteistyötä voitaisiin kehittää esim. jonkin alakohtaisen koulutuskokonaisuuden osalta. Samalla oppimateriaalin kartoitus sekä opettajien käytössä olevien käsikirjojen ja AV-materiaalin että oppilaille jaettavan materiaalin osalta on tarpeen. Hallinnollista päätöksentekoa edellyttävät puolestaan koulujen opetustilojen ja välineiden työsuojeluvaatimukset.

Sisällöllisessä kehittämisessä olisi hyödynnettävä ammattien ja työn tutkimista ja suunnittelun lähtökohtana pitäisi olla nykyistä täydellisempi käsitys koulujen työoloista ja opetustyöstä.

\section{Lähteet:}

Hakkarainen, R., ylitarkastaja, ammattikasvatushallitus, puhelimitse saatu tieto huhtikuu 1987.

Koulutuspoliittinen ohjelma. Työterveyslaitos 1981.

Ohje koulutusammatin opetussunnitelman kehittämiseksi työsuojeluopetuksen osalta. OPS-tiedote N:O 3:1983. Ammattikasvatushallitus. Opetussuunnitelmatoimisto. Helsinki 1983, 3.

Opettajien opintopäivät ja täydennyskurssit vuonna 1984, N:o 4901/128/83. Ammattikasvatushallituksen jakelukirje 15/AOT/83 ja liite: Opettajien täydennyskoulutuskurssiesityksen laadintaohje.

Reunanen, M.: Selvitys opettajien käsityksistä työsuojeluopetuksesta ammattikouluissa. Tampereen aluetyöterveyslaitos 1986.

Työsuojelu ammattikouluissa. Perustietoja määräyksistä, ohjeista ja menettelytavoista. Ammattikasvatushallitus 1982, Helsinki 1982.

Työsuojeluopetus keskiasteen ammattillisessa koulutuksessa. Opetusministeriön keskiasteen koulunuudistuksen johtoryhmän työsuojelujaoston mietintö. Helsinki 1977.

Työsuojelu. Kirjassa: Läpäisyaiheet 83. Suunnitelma läpäisyvaiheiden opettamiseksi ammatillisissa oppilaitoksissa. Ammattikasvatushallitus. Helsinki 1984. Sosiaali- ja terveysministeriön työsuojelun koulutusja tiedotusryhmän muistio. Työryhmä 1986:14.

Valtakunnallinen työympäristöohjelma. Sosiaali- ja terveysministeriö. Helsinki 1984. 